\title{
Management mechanism of human capital formation under a postindustrial economy
}

\author{
Nazirkhan Gadzhiev ${ }^{1, *}$, Sergey Konovalenko ${ }^{2}$, Mikhail Trofimov ${ }^{2}$, Jamila Leontieva ${ }^{3}$, and \\ Khamida Akhmedova ${ }^{4}$ \\ ${ }^{1}$ Dagestan State University, 43-a Gadzhieva str., 367000, Makhachkala, Russia \\ ${ }^{2}$ Ryazan branch of Moscow University of the MIA of Russia named after V. J. Kikot, street 1-I Red, \\ 18, 390043, Ryazan, Russia \\ ${ }^{3}$ Saint Petersburg state University of Economics, 21 Sadovaya street, 191023, Saint Petersburg, \\ Russia \\ ${ }^{4}$ Moscow state University of technology and management. K. G. Razumovsky (PKU), 73 Zemlyanoy \\ Val street, 109004, Moscow, Russia
}

\begin{abstract}
The article is devoted to the study of unsolved problems of the human capital theory, as follows the determination of the mechanism of human capital formation, methods of economic analysis of its effectiveness and accounting costs for its formation. The authors rely on the approach to the definition of "human capital" generally accepted in the economic theory, in terms of which it is a complex of knowledge and the most important resource for sustainable development of the economy, as well as on the structural and systematic approaches, according to which the components of human contribute to the sustainable development of the economy capital acting in concert with each other. In this setting, the main unit of human capital is the member of the creative class. The authors consider a cost approach as the methodological basis for accounting and evaluating human capital in practice. As the main research methods, the authors use the model-building technique for the formation and accumulation of human capital, special methods of economic analysis and statistics. The theoretical and practical significance of the study lies in identifying the management mechanism of human capital formation and validation of the integrated assessment methods and the methods of accounting the effectiveness of the costs of developing human capital in the enterprise management system, which were tested when measuring the effectiveness of the particular enterprise's investments in human capital.
\end{abstract}

\section{Introduction}

At the present stage of development of society in a market economy, the problem of an effective mechanism for the formation of human capital remains scientifically debated. For the intensive development of the logistics industry, a mechanism for the development of human capital is needed.

"Corresponding author: nazirhan55@mail.ru 
In the development of the theory of human capital, theoretical studies of the economic content of models for the formation of human capital and assessing their impact on the sustainability of the socio-economic development of business entities are of particular importance. Conceptually, the mechanism of human capital formation is directly related to two aspects:

firstly, with an objective definition and assessment of the costs of the formation and development of human capital;

secondly, with the proper organization of accounting for the above costs, as well as determining the effectiveness of their return.

Thereby, the scientific problem of the mechanism of formation of human capital lies both in the field of control theory (management) and management accounting, which makes this topic relevant and significant for modern economic science.

The aim of the present study was to investigate the mechanism of formation and functioning of the human capital on the basis of constructing models of its formation, evaluation and accounting for development costs of human capital in economic subjects management.

As the objectives of the study should highlight:

- determination of the nature and role of human capital from the position of domestic and foreign scientists economists;

- determination of the basic models for the formation of human capital in the conditions of the modern post-industrial economy;

- research of the system for assessing the costs of the formation and development of human capital;

- research the basics of constructing a system of cost accounting of investments in human capital.

\section{Theoretical approaches to building models of the formation and accumulation of capital in a post-industrial economy}

Studying the features of the socio-economic development of dynamically developing countries, we can state that increasing the level and quality of life of poor people does not depend on the availability of natural resources or applied technologies, but on the person's knowledge and skills that can be formed and increased by appropriate investments, as a result of which the so-called human capital is formed [3, p. 460].Investments made in a person allow him to occupy either a higher-paying position or to ensure stable entrepreneurial income in the future. The first mention of the term "human capital" is associated with the name of the great economist Theodor Schulz [1, p. 14]. The follower of T. Schulz was Gary Becker, who in 1965 substantiated the need for investment in human capital and determined the economic approach to human labor [2, p. 3]. According to number of economists, human capital acts as an engine of competitiveness of organizations.

Human capital is a certain stock of knowledge, health, skills, and abilities that has been formed as a result of investments and accumulated by a person himself that is appropriate to use in the process of labor activity and which lead to an increase in its productivity [4, $\mathrm{p}$. 32].

The most relevant definitions of human capital characterize it as "people, their productivity and their potential in the organization" [5, p. 3].

Another approach to the definition of human capital is associated with the concept of sustainable development. The latter is understood as "the level of development of the population and the resource that can be used to achieve sustainable development of the 
country" [6, p. 18].

The interpretation of human capital can also be carried out from a position of accounting. Capital is the ability that appears in the balance sheet liability, which must be maintained for a given period. With this approach, human capital is considered as the basis of all economic activity. [7, p. 1375].

In modern economic theory, human capital is considered as a combination of knowledge and the most important source (resource) of the development of society. The resources of each species are determined by their components. In the theory of human capital, the following components of human capital are distinguished: health, morality, creativity, activity (passionarity), organization, assertiveness, education, professionalism, and resources of working time.There is a point of view according to which each of the components of human capital can be considered as an independent resource, however, we believe that this point of view is controversial, since only in the system each of the elements described above makes it possible to create new, that is, forms creativity - the main category sustainable development.

At the same time, we consider it possible and necessary to rank the components of human capital according to the degree of significance, which will allow us to characterize human capital and determine the relevant indicators in the context of objects of managerial analysis. According to our studies, among the most significant components, the leading place is taken by health, creativity (talents, professional skills, horizons, etc.), and the quality of education (see table 1).

Table 1. The characteristic of human capital and the corresponding indicators in the context of objects of management analysis

\begin{tabular}{|c|c|c|c|c|}
\hline \multirow{2}{*}{$\begin{array}{l}\text { Compo- } \\
\text { nents }\end{array}$} & \multicolumn{3}{|c|}{ Objects of management analysis and related indicators } & \multirow{2}{*}{$\begin{array}{l}\text { Rating } \\
\text { points }\end{array}$} \\
\hline & Human & Company & Society & \\
\hline Health & $\begin{array}{l}\text { Capacity for work. } \\
\text { Time of absence at } \\
\text { work due to } \\
\text { disability }\end{array}$ & $\begin{array}{l}\text { Loss of working time due } \\
\text { to illness and injury. The } \\
\text { cost of maintaining a } \\
\text { healthy workforce }\end{array}$ & $\begin{array}{l}\text { Average life expectancy. The } \\
\text { cost of medicine. Mortality } \\
\text { among economically active } \\
\text { population }\end{array}$ & 6 \\
\hline Moral & $\begin{array}{l}\text { Attitude to other } \\
\text { members of society }\end{array}$ & $\begin{array}{l}\text { The relationship between } \\
\text { employees. The damage } \\
\text { from the conflict. Fraud }\end{array}$ & $\begin{array}{l}\text { Attitude towards the } \\
\text { disabled, children, } \\
\text { dependents. Crimerate, } \\
\text { socialtension }\end{array}$ & 1 \\
\hline $\begin{array}{c}\text { Creativepot } \\
\text { ential }\end{array}$ & Creative abilities & $\begin{array}{l}\text { The number of inventions, } \\
\text { patents, rationalization } \\
\text { proposals, innovative } \\
\text { products per worker. }\end{array}$ & $\begin{array}{l}\text { ncome from copyright. The } \\
\text { number of patents and grants } \\
\text { per resident of the country. } \\
\text { Rates of scientific and } \\
\text { technical progress and R\&D } \\
\text { expenses }\end{array}$ & 4 \\
\hline Activity & $\begin{array}{l}\text { The pursuit of } \\
\text { ability. Enterprise }\end{array}$ & & & 3 \\
\hline $\begin{array}{c}\text { Organizatio } \\
\mathrm{n} \\
\text { andassertive } \\
\text { ness }\end{array}$ & $\begin{array}{l}\text { Accuracy, } \\
\text { rationality, } \\
\text { discipline, } \\
\text { commitment, } \\
\text { decency, goodwill }\end{array}$ & $\begin{array}{l}\text { Losses from violations of } \\
\text { discipline and routine. } \\
\text { Purity. Diligence. } \\
\text { Effectivecollaboration. }\end{array}$ & $\begin{array}{c}\text { Quality regulatory } \\
\text { framework. The quality of } \\
\text { infrastructure. Respect for the } \\
\text { interests of citizens and legal } \\
\text { entities }\end{array}$ & 2 \\
\hline Education & $\begin{array}{l}\text { Knowledge. } \\
\text { Duration of study at } \\
\text { school, college and } \\
\text { university }\end{array}$ & $\begin{array}{l}\text { The share of specialists } \\
\text { with higher and secondary } \\
\text { education in the total } \\
\text { number of employees. } \\
\text { Staffdevelopment costs }\end{array}$ & $\begin{array}{l}\text { The average number of years } \\
\text { of study at school, college } \\
\text { and university. The } \\
\text { proportion of expenditure on } \\
\text { education in the state budget }\end{array}$ & 5 \\
\hline
\end{tabular}

The smallest mark in the study was given to such components of human capital as morality and organization. In our opinion, their low significance is the result of a changed system of values as a result of structural restructuring of all spheres of human life in 
Russian society, primarily in the youth sphere.

Today in the world and, in particular, in Russia, the so-called "creative class" is being formed, consisting of people involved in solving important technical, innovative, scientific and other tasks based on independent thinking, creative abilities and a high level of education. This is a special rational type of people for whom knowledge, individual characteristics and personal merits (career) are important.

The realities of life in a post-industrial society (informatization, globalization and integration of all vital processes) form the personality of the employee, aimed at obtaining a result (life success). Such previously necessary components as activity, organization and discipline of employees have become less relevant. People with a "creative" identity have a volatile and irregular schedule, working outside the organization and, sometimes, relaxing at work. The more intensive use of time and effective achievement of the goal, rather than the schedule and the number of hours spent, are of central importance. This is due to the fact that creativity is a property that cannot be activated or turned off according to the established schedule and daily routine.

The management mechanism for the formation and accumulation of human capital has not been studied. In this regard, we consider it necessary to study the basic models of the formation and accumulation of human capital in the post-industrial economy.

1. The "absorption" model is the most cost-intensive model of the formation of "human capital". It is implemented by large companies in cooperation with the most progressive universities and leading universities of the country. The university in this model acts as a key element of the "creative" economy, performing three interrelated tasks reflected in the idea of "3-T" creative centers - Technology, Talent, Tolerance [8, p. 704].

1) Technology development. Universities are the scientific basis for innovative research in various fields: from nanotechnology to bioengineering, they are important sources of creativity, new technologies and future profits of companies.

2) Development of tolerance. Universities contribute to the formation of a calm and tolerant attitude; usually they do not pay attention to national, racial, gender, etc. differences.Talent development. Universities accumulate talented people and various specialists in their field. Educational institutions generate business incubators, scientific laboratories that create and develop innovations.

The role of companies is to financially support the creative activities of universities [9, p.75]. The mechanism of absorption (capture) of human capital is presented in table 2 .

Table 2. The mechanism of absorption of human capital. Model 1.

\begin{tabular}{|l|l|l|}
\hline Stages of human capital formation & $\begin{array}{l}\text { Methods, mechanism of } \\
\text { implementation }\end{array}$ & Note \\
\hline 1. Selection of applicants & $\begin{array}{l}\text { Conducting Olympiads, } \\
\text { children and youth scientific } \\
\text { competitions }\end{array}$ & $\begin{array}{l}\text { Universities play a leading role at } \\
\text { this stage. }\end{array}$ \\
\hline $\begin{array}{l}\text { 2. Student'sinvitationtopractice } \\
\text { Conclusion by a company of } \\
\text { contracts, agreements with a } \\
\text { university or student }\end{array}$ & $\begin{array}{l}\text { Universities play a leading role, but } \\
\text { the role of the company is growing, } \\
\text { especially in the development of } \\
\text { "business incubators" }\end{array}$ \\
\hline $\begin{array}{l}\text { 3. Presentation of grants and } \\
\text { scholarships to the most gifted } \\
\text { students and graduate students }\end{array}$ & $\begin{array}{l}\text { The establishment of special } \\
\text { awards, prizes and grants. }\end{array}$ & $\begin{array}{l}\text { Universities play a leading role at } \\
\text { this stage. }\end{array}$ \\
\hline $\begin{array}{l}\text { 4. The guarantee of the company } \\
\text { getting a job at the end of the } \\
\text { training period }\end{array}$ & $\begin{array}{l}\text { The guarantee of the company } \\
\text { getting a job at the end of the } \\
\text { training period }\end{array}$ & $\begin{array}{l}\text { Companies play a leading role; } \\
\text { universities are of minimal } \\
\text { importance }\end{array}$ \\
\hline $\begin{array}{l}\text { 5. Organization of internships and } \\
\text { retraining, advanced training }\end{array}$ & $\begin{array}{l}\text { Appointment to a higher } \\
\text { position, the possibility of } \\
\text { independent, creative work. }\end{array}$ & CompaniesLead \\
\hline
\end{tabular}

Using this model guarantees the formation of the necessary qualities of a future 
employee; increases the loyalty of an employee of the company and contributes to the assimilation of the main goals, mission and tasks of the company; creates conditions for the subsequent concentration of human capital, forms the creativity of human capital.

The disadvantage of the model is manifested in significant costs for the formation of a creative employee, long periods of investment in human capital, and the possibility of "luring" the employee by competing firms.

2. The "accession" model is used by large manufacturers and is associated with the "outsourcing" system. This system has two advantages: it provides an opportunity for creative firms not to be distracted by production and direct all efforts towards developing promising innovative products or technologies. In turn, subcontractors can increase their benefits and minimize risks due to the effect of a positive growth in the scale of production. The mechanism of accession of human capital can be represented in Figure 1.

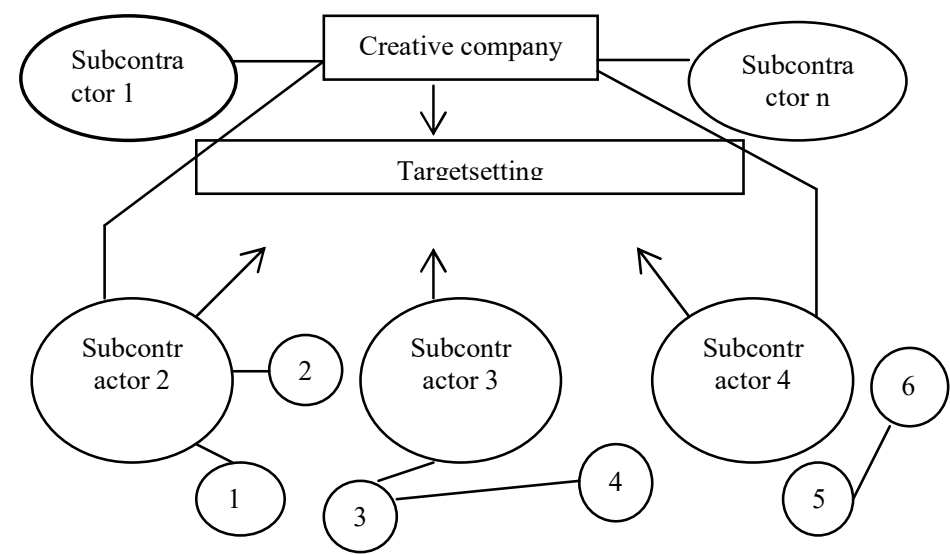

Fig. 1. The mechanism of consolidation of human capital. Model 2.

The advantages of this model also lie in the fact that subcontractors can attract third-party workers and third-party companies (units of human capital) to achieve their goals, which in turn can add additional units of human capital, while "joining" can go far beyond the boundaries of one geographical segment.

The disadvantages of the model are the significant costs involved in attracting specialized contractors, the practical ability to form, but not accumulate human capital. In addition, if the connection with one of the subcontractors is broken, the target setting may not be achieved in the planned time.

3. According to the "spontaneous-individual" model, the formation of a creative personality takes place on the basis of individual preferences and individual's life experience. A person independently chooses what knowledge he needs at the moment, while he usually does not prefer to focus on only one type of activity. A creative person is not afraid to carry out the development of new ideas and projects by trial and error. Such a worker can repeatedly change the sphere of his interests, work, profession, life, dating, etc., over the course of a decade. The associations, unions, companies or societies formed by them are the driving force behind the development of the economy, culture and science, and constitute the creative class of society.

In the modern economy, the models for the formation of human capital are constantly changing, the creative person is less and less in need of the support of large companies and research centers, it is becoming a self-sufficient system capable of independently functioning and developing. Under the conditions of informatization of society, units of human capital easily form spontaneously functioning systems (the core of the creative system), which also easily disintegrate, as a result of these processes the accumulation of 
"new knowledge" takes place.

\section{Methodological approaches to the assessment and accounting of expenses for the formation of human capital}

The problem of estimating and accounting for expenses on the formation of human capital is still unresolved. According to modern research, the quality of human resources in ensuring sustainable socio-economic development is a key factor in ensuring the growth, efficiency and innovative development of the economy [10, p. 358]. Accordingly, one of the most effective indicators for assessing human capital is the "Human Capital Index per capita," which today is called the "Human Potential Index". This indicator characterizes the share of the costs of the state, companies and individuals to education, medicine and other components of human potential per capita.

According to the results of the study, the Russian Federation ranked 34th in the global ranking with an index of 0.73 with a maximum index value of 1 . Adults have a negative impact on the final index (0.78), which corresponds to 122 nd place in the world nearby with Afghanistan. For comparison: the indicator of Norway - 0.94, the United States - 0.9. At the same time, in terms of the quality of education, the Russian Federation is in the group of leading countries (538 percentage points), while in Norway the indicator is 512 , and in the USA - 523. Singapore is the world leader in the Human Potential Index (0.88), in the second and third place - South Korea and Japan. Of the EAEU member countries, our country is ahead of Kazakhstan (0.75), Kyrgyzstan has an indicator of 0.58 (76th place), and Armenia - 0.57 (78th place). Belarus did not participate in the 2018 project, but is preparing to compile an index and join the International Program for the Assessment of Student Educational Achievements.No less significant indicator characterizing human capital is the "Index of the Intellectual Potential of Society" (I.I.P.), which takes into account the quality of education in society and the state of the scientific sphere.

The United Nations Organization publishes an annual report on indices and indicators of human development, which characterize, inter alia, investments in human capital. According to the UN report, our country is 49th out of 189 countries in the Human Development Index and its value is 0.816. The index component is: the gender development index, the human security index, the index of perception of well-being, environmental sustainability, and socio-economic sustainability.

From a market perspective, human resources are valuable. An individual's value for an organization can be defined as the current value of a set of deferred services that the employee is expected to provide for the period during which he / she works in the organization. The organization is not so much interested in the absolute value of the service value, but rather the relative value of the service value (the cost per employee, unit area, capacity, etc.). In this regard, a new concept of accounting and assessing the value of human capital (from the English. "Human resources accounting"), called the HRM, appeared. The HRM concept developers believe, for example, that significant financial resources allocated for the acquisition and training of human resources should be reflected in the financial statements. Otherwise, the results of current activities are distorted by the inclusion in the expenditure part of costs that have long-term consequences.

Representatives of the HRM concept strive to assess the level of uncertainty of future employee services using stochastic mathematical models. There are two aspects to the value of employee services: (1) which the organization could potentially realize if the employee retains membership in the organization for the entire working age (usually retirement time is assumed), and (2) the value of services that the organization can really expect, given the fluidity. Consequently, the process of providing services by employees is probabilistic. In the first case, they talk about the expected conditional value, in the second - about the 
expected realized value of the employee. The latter is of particular interest from the point of view of the employer. When assessing the added value of personnel activities, the expected duration of the services is taken into account.

Calculation of the value of the employee's services is based on an assessment of his labor productivity. Productivity depends, in turn, on a combination of skills (skills) and employee activity, which set general limits on the size and nature of the services sold by him [11].

The employee's value for the company is established on the basis of the expected conditional value of the employee and the likelihood of his retaining membership in the organization:

$$
C_{n}=\operatorname{Cou} \times \text { Ons }
$$

where

$\mathrm{Cr}$ - employee realizable value;

Cou - employee contingent value;

Ovs - assessment of the likelihood of an individual continuing to work in a firm.

However, the model for assessing human capital studied above does not, in our opinion, take into account the effect of raising and retraining personnel.

Therefore, the effect of training should be determined by the formula:

$$
E=T \times N \times V \times K-N \times C
$$

whereT-the duration of the impact of the program (years) on labor productivity and other factors of its effectiveness;

$\mathrm{N}$-number of trained and retrained personnel;

$\mathrm{V}$-valuation of differences in value for the company of the "best" and "average" workers performing typical duties (conventional units);

$\mathrm{K}$-a coefficient that determines the effect of employee training (growth in the value of the employee who completed the training, expressed in fractions V);

$\mathrm{C}$-training costs per employee (in conventional units).

The positive effect of training is determined by the fact that the results of the work of "average" ("bad") workers begin to be attracted to the "best", the work of the latter also improves, and the overall labor productivity of the enterprise increases. The value of the results of labor of employees who have undergone training is increasing (improving the quality of work, reducing the cost of production). However, the duration of the beneficial effect is limited in time.

Another approach to assessing the value of human capital is based on the application of the "substitution effect", which is defined as the amount of costs required to replace one employee with another (including the costs of treatment and accommodation of staff) [12]. The effect of the substitution effect is associated with the specifics of the functioning of the labor market (seasonality, business activity, economic cycles, etc.) and the psychological characteristics of the employee (discipline, the nature of relationships with colleagues, personal qualities, etc.).

In our opinion, the costly approach is the most acceptable in the conditions of the Russian economy, it focuses on the traditional system of accounting, planning and analysis that had developed in Soviet times. The cost approach involves the introduction of the estimated principle and the use of reporting and planning documentation, characteristic of the traditional accounting system for the costs of production and calculation of products (works, services). The application of the costly approach allows one to take into account deviations from the norms, analyze them in a timely manner, and identify reserves for increasing the efficiency of investments (see Figure 2). Moreover, the costs of forming human capital can be tied to the size and dynamics of financial results, and they can be forecasted for the medium and long term for the company.

The use of a costly hike allows management personnel to make the right and informed 
decisions in the personnel field of an economic entity. For the purposes of analyzing the results of the formation of human capital with a costly approach, indicators such as labor costs, employee training and retraining costs, research and development (R\&D) costs per person, gross income (revenue) are used per employee, etc. [13].

With a costly approach, we propose to measure the effectiveness of the return of human capital using the "replacement" coefficients, which characterize the ratio of income indicators per employee and the cost of forming human capital.

$$
K 1=V d / z
$$

where $K 1$ - replacement rate 1 ,

$V d$ - gross income per employee,

$z$ - human capital formation costs;
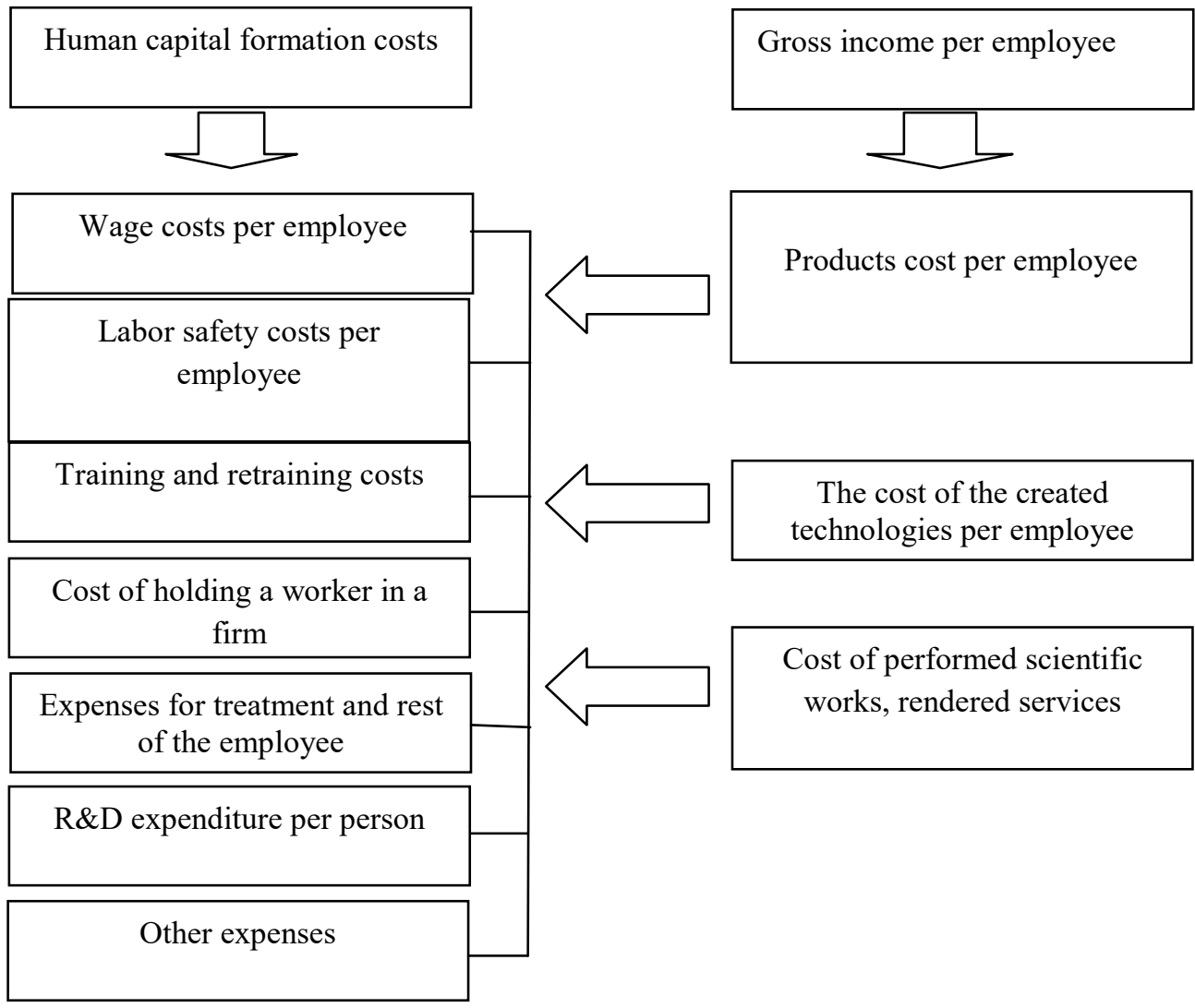

Products cost per employee

The cost of the created technologies per employee

Cost of performed scientific works, rendered services

Fig. 2. Cost approach in assessing the value of human capital

$$
K 2=S p / z
$$

where K2 - replacementrate2,

$\mathrm{Sp}$ - cost of marketable products per employee,

$\mathrm{z}$ - human capital formation costs;

$$
K 3=S t / z
$$

where K3 - replacementrate3,

St - cost of created technologies per employee,

z - human capital formation costs; 


$$
K 4=S r / z
$$

where $K 4$ - replacementrate4,

$\mathrm{Sr}$ - the cost of scientific work performed, services rendered per employee

$z$ - human capital formation costs.

An increase in replacement ratios will indicate an increase in the return on human capital and an increase in the efficiency of its return. At the same time, an important drawback of such a methodology is the difficulty in establishing uniform norms and standards for relative indicators of the effectiveness of the return on human capital, since the duration of the life cycle of human capital is different in different sectors of production and, as a consequence, the total costs of its formation are different.

Table 3 presents the performance indicators of the return on human capital by the example of JSC Gazprom Gas Distribution Ryazan Region. Of greatest importance in the organization is the "substitution" coefficient for gross income of more than 0.803 , which shows that, for each ruble spent on the formation of human capital, the company guarantees itself an income of 80 kopecks. It should be noted that when calculating the indicator, both external and internal costs of the company are taken into account (costs of retaining an employee in the company).

Table 3. Efficiency of the return of human capital by the example of AO Gazprom gazoraspredelenieRyazanskaya oblast (a gas distribution company in Ryazan Region, Russia, a

limited liability company under the laws of the Russian Federation) for 2018

\begin{tabular}{|c|c|c|c|c|c|c|c|}
\hline \multirow[b]{2}{*}{ 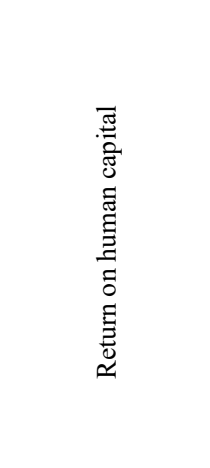 } & \multirow[b]{2}{*}{ 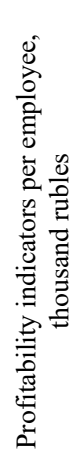 } & \multicolumn{5}{|c|}{ The cost of the formation of human capital, thousand rubles } & \multirow[b]{2}{*}{ 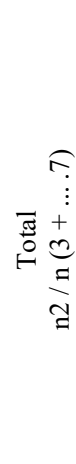 } \\
\hline & & 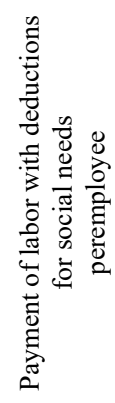 & 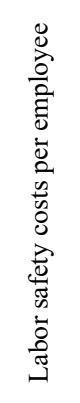 & 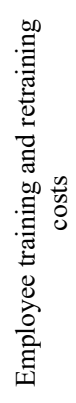 & 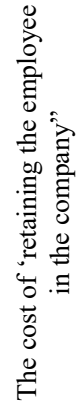 & 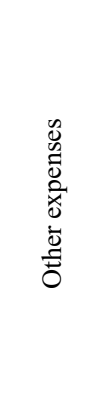 & \\
\hline K1(replacement) & 4732 & $1,495.6$ & 126.5 & 275.6 & 345.6 & $3,652.9$ & 0.803 \\
\hline K2 (replacement) & 4325 & $1,495.6$ & 126.5 & 275.6 & 345.6 & $3,652.9$ & 0.734 \\
\hline K3 (replacement) & 2850 & $1,495.6$ & 126.5 & 275.6 & 345.6 & $3,652.9$ & 0.483 \\
\hline K4 (replacement) & 920.1 & $1,495.6$ & 126.5 & 275.6 & 345.6 & $3,652.9$ & 0.252 \\
\hline
\end{tabular}

In our opinion, the optimal ratio of the income received and the costs incurred for the formation of human capital is a 2: 1 ratio, that is, for each ruble spent in the formation of human capital, an income of 2 rubles can be obtained.

We believe that the effectiveness of the return on investment in human capital should be judged in full not by individual indicators, but on the basis of a study of a comprehensive rating value. Thisindicatormaybe the Generalized coefficient of return.

$$
K(i)=K 1 \times K 2 \times K 3 \times K^{4} \text {, }
$$

Using a rating assessment will more accurately and efficiently track the change in the effectiveness of the organization's human capital investments, while comparisons can be made both with individual manufacturers of this industry, and with enterprises of other industries. The rating system is presented in table 4 .

Characterizing the coefficient of return by classes, we can state that:

Grade 1 - a low level of investment in human capital (a substantial incentive to invest in 
human capital is necessary, costs should be increased).

Grade 2 - a moderate level of investment in human capital (it is necessary to revise the cost structure, identify weaknesses, stimulate individual cost components in human capital).

Grade 3 - the average level of ensuring investments in human capital (there is no need to increase costs, it is required to identify reserves for increasing the efficiency of certain types of activities).

Grade 4 - a high level of investment in human capital (costs should be left at the achieved level, but it is necessary to ensure the achieved level of R\&D).

Grade 5 - a very high level of investment in human capital (it is necessary to prevent the growth of unjustified expenses while maintaining the achieved level of efficiency).

Table 4. Rating of human capital of an enterprise

\begin{tabular}{|c|c|}
\hline Recoil ratio & Rate \\
\hline 1 grade & lessthan 0.05 \\
\hline 2 grade & from 0.05 - to 0.1 \\
\hline 3 grade & from 0.1 to 0.5 \\
\hline 4 grade & from 0.5 to 1 \\
\hline 5 grade & more than 1 \\
\hline
\end{tabular}

According to the presented methodology, the return coefficient K (i) for the organization of AO Gazprom gazoraspredelenieRyazanskaya oblast will be 0.072 , which corresponds to grade 2.The company needs to adopt a strategy to increase investment in human capital and, above all, increase the cost of scientific work performed, services rendered per employee, the company does not allocate funds for R\&D enough, and their effectiveness is relatively low.

- The cost estimation system is inextricably linked with the organization of accounting. The need for accurate and efficient cost accounting is dictated by the action of a market mechanism aimed at generating constant profit for companies.

- There are various approaches to accounting for investments in human capital, most of which are associated with the organization of management accounting for the costs of production and management. We propose to include in section 3 "Production Costs" of the working chart of accounts special management accounting accounts. As accounts, it is proposed to open an account 27 or 30 "Investments in human capital". Creating a new account will require changes in the accounting policies of the organization. The use of these accounts in the management accounting system will allow:

- generate objective information about the analytical structure of expenditures in human capital;

- generate information necessary for owners (accurately assess investments in human capital, determine an effective strategy for the development of the company, etc.);

- to form the cost and financial results taking into account investments in human capital[14].

Based on the directions of investments in human capital to account 27 (30), you can open the following sub-accounts:

- 27-1 (30-1) "Remuneration of labor with deductions for social needs per employee";

- 27-2 (30-2) "Costs of training and retraining of an employee";

- 27-3 (30-3) "Costs for safety and health";

- $27-4$ (30-4) "The cost of retaining an employee in the company";

- 27-5 (30-5) "Otherexpenses".

Sub-account 27-1 (30-1) "Payment of labor with deductions for social needs per employee" is intended to generate information on the cost of labor with deductions for 
social needs of employees of the organization ".

Subaccount 27-2 (30-2) "Costs of training and retraining of an employee" is intended to generate information on costs associated with improving the level of knowledge and improving the professional skills of employees.

Subaccount 27-3 (30-3) "Costs for safety and health" is intended to reflect information on costs aimed at maintaining and improving the health of workers, as well as ensuring safety at work.

Subaccount 27-4 (30-4) "Costs of" retaining an employee in a company "is intended to reflect information on costs of activities related to increasing employee motivation, team building, organizing leisure activities for employees, improving housing conditions, and valuable gifts.

In the debit of sub-account 27-5 (30-5) "Other costs", costs that have a small share in the costs of developing human capital (less than $5 \%$ of total costs) should be taken into account. Costs of investments in human capital are recorded by correspondence on the debit of account 27 (30) "Investments in human capital" and credit of accounts of material values and works, services: $41,23,76,71.73,79$, etc. At the end of investments, the costs are written off from the credit of account 27 (30) to the debit of account 90.2 "Expenses for current activities" in the planned (normatively approved) amount. If the standards for the approved estimates are exceeded, the costs of investing in human capital should be debited to account 99 "Profits and losses". The proposed methodology will allow using account 27 (30) "Investments in human capital" to track the costs of investments in human capital using the accounting methodology.

\section{Results}

When studying the mechanism of the formation of human capital in a post-industrial economy, we can draw the following conclusions:

Firstly, in modern economic theory, human capital is considered as a body of knowledge and the most important resource for economic development. The resources of each species are determined by their components.

Secondly, in the modern post-industrial economy, the models for the formation of human capital are constantly changing, the creative person is less and less in need of the support of large companies and research centers, it is becoming a self-sufficient actor, capable of independently functioning and developing. Under the conditions of informatization of society, units of human capital easily form spontaneously functioning systems that also easily disintegrate. As a result of these processes, the accumulation of "new knowledge" takes place.

Thirdly, at present, the management mechanism for the formation of the necessary "productive knowledge" during the life cycle of human capital has not been studied much. In this regard, we examined the basic models of the formation and accumulation of human capital in the post-industrial economy (the model of "absorption, model of" accession "," spontaneous-individual "model).

Fourth, in the system of evaluating investments in human capital, we recommend the use of a cost-based approach, which is the most acceptable in the Russian economy, it focuses on the traditional system of accounting, planning and analysis that was established in Soviet times. The cost approach involves the introduction of the estimated principle and the use of reporting and planning documentation, allows you to take into account deviations from the norms and analyze them in a timely manner, to identify reserves for increasing the efficiency of investments. Moreover, the costs of forming human capital can be tied to the size and dynamics of financial results, and they can be forecasted for the medium and long term for the company. The use of a costly trip allows management personnel to make the 
right decisions in the personnel sphere of an economic entity.

Fifthly, the effectiveness of the return on investment in human capital should be fully judged not by individual indicators, but based on the study of a comprehensive rating value. In the article we have given a practical example of calculating the rating score for the effectiveness of investments in human capital, while the rating score is divided into 5 corresponding classes. Each rating class characterizes the prevailing level of investment in education, healthcare, scientific development, improvement of professional skills and skills of employees. The analyzed organization is characterized by a 2 class rating rating, reflecting a moderate level of ensuring investments in human capital, in connection with which, the company's management is recommended to increase the cost of scientific development and innovative technologies per employee, to increase the coefficient of renovation of production fixed assets.

The results of the rating calculation using the example of AO Gazprom gazoraspredelenie Ryazanskaya oblast are presented on the graph (see Figure 3).

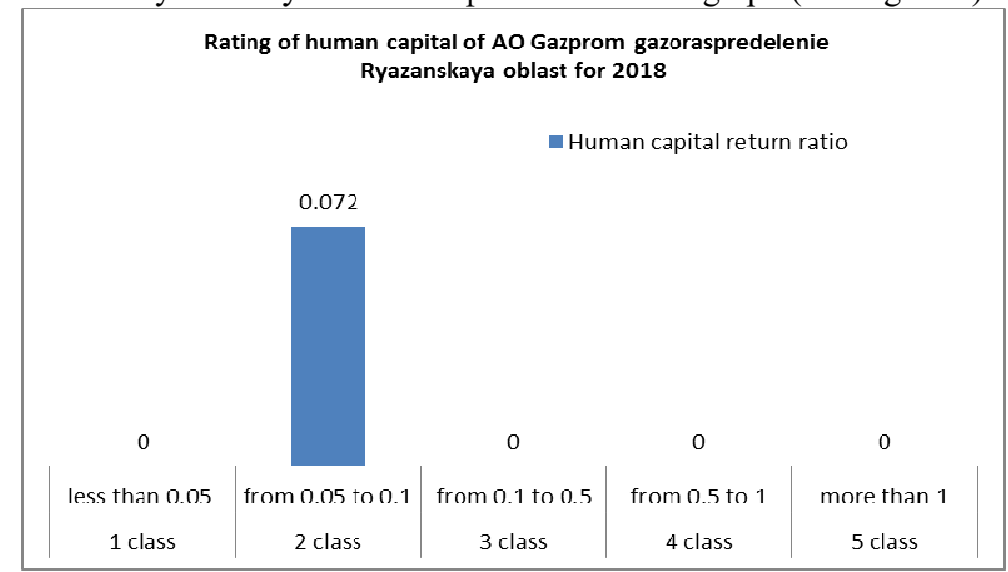

Fig. 3. Graphical model of human capital rating (Gazprom gas distribution Ryazan region JSC for 2018)

Sixthly, to account for investments in human capital, it is proposed to use a system of managerial accounts that allows you to account for and write off these expenses. The proposed methodology will allow using managerial account 27 (30) "Investments in human capital" to evaluate the effectiveness of investments in human capital from an accounting perspective. According to the recommendations of the authors, at the end of the reporting period, the recorded costs in account 27 (30) are debited from the credit of the account in the debit of account 90.2 "Expenses for current activities" in the planned (normatively approved) amount, and if the standards are exceeded, the costs of investing in human capital should be write off to account 99 "Profit and loss". Such an approach will provide an opportunity for the company's management to take into account the effective costs of forming human capital in the cost structure of products (works, services), and not to attribute the effective costs to the losses of the company, while receiving detailed information about specific individuals, divisions that have negative results regarding investments in human company capital.

\section{Conclusion}

The problem of studying the managerial mechanism for the formation of human capital is a poorly studied and debatable topic in the scientific field. The effectiveness of investments in human capital depends on many factors, primarily on the specifics of evaluating the 
components of human capital, the adopted strategic model for the formation and development of human capital, an effective cost accounting system and analysis of the effectiveness of investments made. [15]. Analysis of the components of human capital has shown a different degree of significance for modern society. The smallest mark in the study was given to such components of human capital as morality and organization. In our opinion, the low importance of these components of "human knowledge" is the result of a changed system of values as a result of structural restructuring of all spheres of human life in Russian society, primarily in the youth sphere. The high importance of health and education for society indicates the preservation of the traditional priorities of moving along the career ladder of a "successful" person.

In the study of the main strategic models for the formation of human capital, the " $3-T$ " principle is applied as a unifying principle - technology, talent and tolerance. As a result of the study, it was found that the effectiveness of the return on investment in human capital should be fully judged not by individual indicators, but on the basis of the study of a comprehensive rating value. Using a rating score from our position will allow us to more accurately and efficiently track changes in the effectiveness of the organization's human capital investments.

The proposed option of organizing the accounting of costs for the formation of human capital in the accounts of management accounting will allow using account 27 (30) "Investments in human capital" to track the costs of investments in human capital using the accounting methodology.

It should be borne in mind that the conclusions made by the authors in the framework of a scientific article are mainly theoretical and debatable in nature, but at the same time they are of practical importance in terms of creating a system for assessing and accounting the costs of forming human capital in organizations.

\section{References}

1. T.W. Schultz American Economic Review, 51, 1-17 (1961).

2. G.S. Becker, Human Capital: A Theoretical and Empirical Analysis with Special Reference to Education. Chicago: University of Chicago Press, (1993).

3. F. Lange, R. Topel, The Social Value of Education and Human Capital, Hanushek E., Welch F. (eds) Handbook of the Economics of Education, vol. 1 Ch. 8 Amsterdam, The Netherlands: Elsevier. 459-509 (2006).

4. N.N. Parasotskaya, S.V. Gus'kov, Auditor. 1, 31-37 DOI:10.12737/article_5c457f4e64cad1.24274990.

5. H. Thomas, R.R. Smith, F. Diez, Human Capital and Global Business Strategy. N.Y.: Cambridge University Press. (2013) DOI:10.1017/CBO9781139519380.002

6. N. G. Gadzhiev, S. A. Konovalenko, M. N. Trofimov et al., South of Russia: ecology, development. 14(4). 17-24, (2019) DOI: 10.18470/1992- 1098-2019-4-17-24

7. Zh. Rishar, Yu.V. Altukhova, Mezhdunarodnyy bukhgalterskiy uchet. 23. 1364 - 1379, (2017) DOI:10.24891/ia.20.23.1364.

8. N.V. Malinovskaya, Mezhdunarodnyy bukhgalterskiy uchet. 11-12, 700 - 713 (2018) DOI:10.24891/ia.21.6.700.

9. Ja.J. Heckman, Voprosy obrazovaniya, 3, 73-138 (2011).

10. B. Voskoboynikov, Higher School of Economics Research Paper, WP BRP 179/EC/2017. DOI:10.2139/ssrn.3070227 
11. J. Eppelsheimer, \& J. Möller, Regional Science and Urban Economics, 78, (2019) https://doi.org/10.1016/j.regsciurbeco.2019.103461

12. M. Flückiger, \& M. Ludwig Economics Letters, 168, 10-14, (2018) DOI:10.1016/j.econlet.2018.03.027

13. Z. Yang, \& Y. Pan, Cities, 98, (2020) DOI:10.1016/j.cities.2019.102577

14. J. Leontieva, L. Tarasova, Y. Boiko and E. Zaugarova, E3S Web Conf., 110, 02017 (2019) DOI:10.1051/e3sconf/201911002017

15. L.S. Burns, \& H.E. Frech De Economist 118, 598-618 (1970). DOI:10.1007/BF02142836 